\title{
Evaluation of Boccia Sports Achievement Coaching Program using Cipp Model at the Boccia NPC Indonesia National Training Center
}

\author{
Andrian Martgatha Kasih ${ }^{1, *}$, M. Furqon Hidayatullah ${ }^{2}$, Muchsin Doewes ${ }^{3}$ \\ Department of Sports Science, Postgraduate Program, Sebelas Maret University (UNS), Indonesia \\ Jalan Ir. Sutami No. 36A, Jebres, Kota Surakarta, Central Java, post code:57126, Indonesia. \\ *Corresponding Author \\ Received: 03 May 2021; Received in revised form: 04 Jun 2021; Accepted: 14 Jun 2021 \\ (일 The Author(s). Published by TheShillonga. This is an open access article under the CC BY license \\ (https://creativecommons.org/licenses/by/4.0/)
}

\begin{abstract}
The present research focus on determining the achievement of the Boccia sports achievement coaching program using the CIPP evaluation model at the Boccia NPC Indonesia National Training Center in 2019/2020.

The type of research used is program evaluation research. The evaluation model used is the evaluation model context, input, process, product (CIPP). Sources of data obtained from three objects namely paper, place and person. Data collection techniques in this research used observation, questionnaires, interviews, and observations. The research instruments are observation guidelines, interviews and questionnaires. The data analysis technique in this research is descriptive data analysis, namely qualitative descriptive data analysis and quantitative descriptive data analysis. The result of the percentage value of context evaluation is $87.5 \%$ in good category, the result of the percentage value of input evaluation is $86.5 \%$ in good category, the result of the percentage value of process evaluation is $88.67 \%$ in good category, and the result of the percentage value of product evaluation is $89,8 \%$ with good category. Based on the results of the evaluation of the questionnaire assessment and has been analyzed using quantitative descriptive data analysis techniques, it can be concluded that the evaluation of the Boccia sports achievement coaching program is categorized as good.
\end{abstract}

Keywords-CIPP Evaluation, Achievement Coaching, Boccia.

\section{BACKGROUND}

Boccia is a game played indoors with a smooth/slippery field surface. The balls used are made of leather. The ball used in the game consists of 13 balls. The ball is divided into: 6 blue balls, 6 red balls and 1 white ball (Jack Ball). These balls also have different characteristics. Athletes who can compete are athletes who have disorders that lead to competitive losses in the sport. There are 4 classifications to be able to compete in Paralympic sports, especially Boccia. The BC1 classification refers to athletes with brain damage who are able to use their hands or feet to consistently move the ball in play. The athletes of this category are accompanied by a guide or assistant to deliver the ball before they make the throw. BC2 are athletes with cerebral palsy but are able to use hands and feet much better than athletes in the $\mathrm{BC} 1$ category. $\mathrm{BC} 3$ are athletes with brain paralysis or other movement dysfunction in all four limbs who are unable to throw the ball in the game so that they are allowed to use assistive devices to move the ball in the game and are assisted by an assistant who is in charge of arranging the ball throwing pathBC4 are athletes who do not have brain paralysis problems but have other movement function disorders in all four limbs and have functional abilities like BCS athletes. Conditions such as muscular dystrophy, spina bifida (open spine) disorders, tetraplegia, fall into this category (Barak, 2016).

Boccia was first competed in Indonesia at the national student level, namely at peparpenas (National Student Paralympic Week) on November 7-14, 2017 in Solo. Out of the 15 provinces that registered, there were 7 provinces that qualified for the event. In Indonesia boccia sports under the auspices of NPC Indonesia. NPC Indonesia (National Paralympic Comitee of Indonesia) 
was previously named YPOC (Foundation for Disabled Sports) and BPOC (Disability Sports Development Agency. Multi event competition participated by NPC Indonesia at the world level "Paralympic Games", Asian level "Asian Para Games", and Southeast Asian level "Asean Para Games".

NPC itself is an institution that is responsible for gathering, fostering, training, and forming high-quality disabled sports athletes and is responsible for coordinating every disability activity at the regional, national and international levels. NPC Indonesia is an achievement sports organization for people with disabilities which is the only forum for training and organizing sports for people with disabilities in Indonesia and has the authority to foster persons with disabilities. The NPC is expected to increase the achievements of boccia athletes to the world level.

The achievements require a good coaching process. The process of fostering achievement in sports has several aspects that must be met, namely biological aspects, psychological aspects, environmental aspects, and supporting aspects. According to Harsono (2017) to achieve high achievement requires hard work, because high achievement is not easy work, but that does not mean it cannot be achieved. To achieve optimal performance requires good physical, technical, tactical and mental wellbeing. Good physical, technical, tactical and mental qualities must have the right training qualities. In addition, to achieve achievements, professional management is needed. Management quality can be seen from several aspects, namely human resources (athletes, coaches, administrators), finance/funding, training programs, and infrastructure.

Indonesia's Boccia national team has not had the best performance at the international level. The first participation of the Indonesian national team in the international arena was the Asian Para Games Jakarta in 2018. The Indonesian national team could not win a medal. To improve the achievements of the Indonesian national team Boccia, evaluation is required from several aspects. Evaluation conducted professionally will produce objective findings that are findings as they are both data, analysis and conclusions are not manipulated which will ultimately benefit policy makers and the public. According to Rusdiana (2017) evaluation is defined as the collection of information in order to make decisions and judgments. Context, Input, Proccess, Product (CIPP) evaluation is expected to produce data findings that can then be used to evaluate the management of the Indonesian national team.

\section{RESEARCH METHODOLOGY}

The type of this research is evaluation research or program evaluation. According to Sugiyono (2016) Evaluation research is a scientific method (rational, empirical and systematic) to obtain data with the aim of knowing the effectiveness and efficiency of projects, policies and programs. According to Arikunto (2017) Evaluation research is a process carried out in determining policies by first considering the positive values and benefits of a program, as well as considering the technical process that has been used to conduct the assessment.

The program evaluation model used in this study is the CIPP evaluation model (context, input, process, product). There are 4 components that will be discussed and evaluated in this study, namely the dimensions of context, input, process, product.

\section{Context dimension}

Evaluating the history of the NPC Boccia Indonesia program organization, the legal basis for the NPC Boccia Indonesia sports program, the objectives of the NPC Boccia Indonesia program.

2. Input dimension

Evaluating the characteristics of Boccia athletes, characteristics of Boccia coaches, support for facilities and infrastructure for the Boccia sports program at NPC, financial support for the Boccia Program at NPC.

3. Process dimension

Evaluating the implementation of the selection of Boccia Indonesia NPC athletes and coaches, the implementation of the Boccia Indonesia NPC training program.

\section{Product dimension}

Evaluating the achievements of NPC Boccia Indonesia.

The data sources in this study were obtained from three objects, namely: paper, place and person. Paper is a source of document data, books, magazines or other written materials in the form of theories, research reports and so on. Place is a data source in the form of a place that is the object of observation with various behaviors or actions of people in that place. Person is the source of data in the form of people (respondents) to meet, to ask questions and to consult; in this case are Management, Coaches, and Athletes. Data collection techniques in this research used observation, questionnaires, interviews, and scrutiny. To evaluate the implementation of the national team sports performance development program for the Indonesian Boccia national team uses research instruments, namely observation guidelines, interviews and questionnaires (questionnaire). The use of instruments 
in the form of a questionnaire (questionnaire) to obtain accurate data requires a data collection tool that can be accounted for by being tested for its validity and reliability.

In this research, two kinds of descriptive data analysis techniques were used, namely qualitative descriptive data analysis and quantitative descriptive data analysis. The data that was analyzed qualitatively came from data obtained from various sources, namely interviews. While the quantitative descriptive based on the data obtained from the questionnaire.

\section{A. Context Evaluation}

\section{RESULTS AND DISCUSSION}

The context dimension or context evaluation aims to evaluate the history or background of the Boccia program at NPC Indonesia, the legal basis, and the objectives of the Boccia sports program. The Boccia Indonesia NPC Program is a sports program organization that has the characteristics of a good organization. This good category can be described as follows: Boccia NPC program has a legitimate organizational structure; this is based on the observation of the latest decision letter determination document number: 01/NPC-Ina/SKEP/IV/2019. In addition, in running the NPC organization Boccia has its Articles of Association and Bylaws. Second, the NPC runs an organization based on a legal basis, both based on the Act and the Government Regulation of the Republic of Indonesia. The three Boccia NPC Programs aim to accommodate the talents of Indonesian citizens, especially people with special needs or disabilities, to be able to excel.

Based on an assessment questionnaire consisting of 20 respondents (management, coaches, assistant coaches, support teams, athletes) and with 6 questions, the total value of the questionnaire obtained was 525. Furthermore, the total assessment changed to a percentage value, from the context evaluation questionnaire obtained a percentage value of $87.5 \%$. Based on the benchmark reference assessment (PAP) the result of the percentage value of context evaluation is $87.5 \%$ with a good category.

\section{B. Input Evaluation}

Input evaluation aims to evaluate the supporting factors in achieving the target of a program. There are several factors that are evaluated in this study, namely HR factors related to athlete characteristics, coach characteristics, facilities and infrastructure support, funding or finance. The following are conclusions based on the results of interviews and document observations. Boccia NPC athletes have various characteristics, according to their respective origins or cultures. The process of breeding athletes is also carried out using various methods, both by means of independent selection, recommendation, and talent scouting to regions. Characteristics of Boccia coaches at NPC Indonesia have knowledge and knowledge of sports that are in accordance with the field of sports, have knowledge about sports with disabilities, especially the boccia sport, have a license and experience in the boccia sport, and have achievements in training the boccia program Supporting documents that strengthen these results are the trainer's certificate, trainer's license, and trainer's achievement certificate. The following is a list of managers, coaches, and support teams for the Indonesian national training team for the Boccia sport. The facilities and infrastructure owned by the Boccia Indonesia NPC team are complete and in accordance with the team's needs. Procurement of training equipment refers to international boccia regulations. However, there are several supporting facilities and the main facilities that the Boccia NPC team does not yet have, namely the field or place to practice and compete, temporarily rent training at the UNS Solo Sports Building. NPC Boccia also does not have facilities for athletes or coaches to live in.

The funds used by NPC Boccia come from the state budget. The fund management process begins with submitting a proposal to the Ministry of Youth and Sports. After the proposal is approved, then the funds are managed by the Boccia NPC management. Fund management is used for training operations, match operations, operational participation of athletes in try outs or boccia competition events, secretarial operations, and procurement of facilities and infrastructure. The Boccia NPC management prepares the annual plan and budget. The budget that has been prepared is then submitted to the Ministry of Youth and Sports.

Based on the input evaluation assessment questionnaire instrument, the total score obtained from the input evaluation assessment questionnaire consisting of 20 respondents (management, coaches, assistant coaches for the support team, athletes) and with 8 questions are 525. Furthermore, the total assessment obtained is converted into a percentage value. Based on the benchmark reference assessment (PAP) the percentage value of the input evaluation is $86.5 \%$ with a good category. 


\section{Proccess Evaluation}

Process evaluation aims to evaluate the selection process for boccia athletes, planning and implementing the boccia sports program. The process of breeding athletes is carried out in several stages. The first stage is the initial nursery; the initial nursery stage is carried out in 3 ways, namely self-registration, regional NPC recommendations, and talent scouting to the regions. The second stage is verification, after the nursery stage is complete, the list of athletes is verified by management, and prospective athletes who have passed the verification then go to the third stage, namely the selection stage. The third stage is selection, prospective athletes who have passed the verification are then selected by a selection team from NPC Boccia, and the selection team consists of coaches, assistant coaches, and support teams. The fourth stage is determination; athletes who pass the next selection are determined to join the national training. Athletes who have joined the National Training Center are then trained and nurtured so that they can excel.

The Boccia NPC team's annual training program is structured around the event's goals and objectives. In addition, in preparing the training program, the coaching team considers several aspects, starting from the national calendar, the calendar of events in the world boccia championships, and the condition of the athletes (physical and technical abilities). The condition of athletes can be seen by measuring the technical and physical abilities of boccia athletes in national training. The test results are used as a reference or indicator for making an annual training program plan. The implementation of the exercise was in accordance with the training program that was prepared, but in the process of implementing the exercise there were several obstacles, namely the changing event schedule, several athletes who were sick, and from 2019 to 2021 the world was being hit by the Covid-19 outbreak, so the training process needed adjustments and training programs that have been prepared need to be reviewed and revised.

Based on the process evaluation assessment questionnaire, the total score obtained from the process evaluation assessment questionnaire is 266 . Furthermore, the total score obtained is converted into a percentage value. Based on the benchmark reference assessment (PAP) the percentage value of the evaluation process is $88.67 \%$ with a good category.

\section{Product Evaluation}

Product evaluation aims to evaluate the results of boccia's previous sports achievement coaching program. Based on interviews and observations of documents it can be concluded that the achievements that have been obtained by Boccia are 3 Silver medals: Individual $\mathrm{BC} 1$; Individual $\mathrm{BC} 2$; Teams BC1/BC2.

Based on the total product evaluation assessment questionnaire, the value obtained is 359 . Furthermore, the total valuation obtained is changed to a percentage value. Based on the benchmark assessment (PAP) the result of product evaluation percentage value is $89.8 \%$ with a good category.

\section{CONCLUSION}

Based on the results of the questionnaire assessment and analyzed using descriptive quantitative data analysis techniques, it can be concluded that the evaluation of the Boccia sports achievement coaching program is categorized as good. The result of the percentage value of context evaluation is $87.5 \%$ in good category, the result of the percentage value of input evaluation is $86.5 \%$ in good category, the result of the percentage value of process evaluation is $88.67 \%$ in good category, and the result of the percentage value of product evaluation is $89,8 \%$ with good category.

\section{REFERENCES}

[1] Arikunto S. 2017. Pengembangan Instrumen Penelitian dan Penilaian Program. Celeban: Pustaka Pelajar.

[2] Barak S., Nuria ML, Maria TGF, Maria R \& Yeshayahu H. 2016. Psychosocial Effects of Competitive Boccia Program in Persons with Severe Chronic Disability. Vol. 53, No. 6.

[3] Harsono. 2017. Kepelatihan Olahraga. Bandung: PT Remaja Rosdakarya

[4] Rusidana, HA. 2017. Manajemen Evaluasi Pendidikan Program Pendidikan: Konsep, Prinsip dan Aplikasinya di sekolah/Madrasah. Bandung: CV Pustaka Setia.

[5] Sugiyono. 2016. Metode Penelitian dan Pengembangan: Research and Development. Bandung: CV. Alfabeta. 